\title{
Usefulness of the Neutrophil Gelatinase-Associated Lipocalin (NGAL) Kit for Acute Kidney Injury Patients at the Emergency Medical Center in Daegu
}

\author{
Seung-Jin Lee ${ }^{1}$ and Sangwook Park ${ }^{2}$ \\ ${ }^{1}$ Department of Laboratory Medicine, Daegu Catholic University Medical Center, Daegu 42472, Korea \\ ${ }^{2}$ Department of Biomedical Laboratory Science, College of Health, Kyungwoon University, Gumi 39160, Korea
}

\section{대구지역 응급의료센터에 내원한 급성 콩팥손상 환자의 진단을 위한 호중구 젤라티나제 관련 리포칼린 키트의 유용성}

\author{
이승진 ${ }^{1}$, 박상욱 $^{2}$ \\ ${ }^{1}$ 대구가톨릭대학교병원 진단검사의학과, ${ }^{2}$ 경운대학교 보건대학 임상병리학과
}

\begin{abstract}
Acute kidney injury (AKI) is a common syndrome resulting in kidney damage and malfunction within a few days or even a few hours. The diagnosis of AKI depends on routine biochemical tests, including serum creatinine, aspartate aminotransferase (AST), alanine aminotransaminase (ALT), blood urea nitrogen (BUN), and electrolytes. Plasma neutrophil gelatinase-associated lipocalin (NGAL) is a biomarker that shows correlation with the severity of acute infections and kidney injuries. The predictive value in other conventional assays for kidney functions has been reported to cause distraction for AKI syndrome. The aim of this study is to verify the predictive value of plasma NGAL in patients with established AKI. The NGAL kit for checkup demonstrates sensitivity of $\geq 300(92.2 \%), \geq 200$ (95.6\%), $\geq 100(99.6 \%)$, specificity of $\geq 300(95.1 \%), \geq 200(97.3 \%), \geq$ 100 (99.4\%), positive predictability of $\geq 300$ (93.3\%), $\geq 200(93.4 \%), \geq 100(99.2 \%)$, and negative predictability of $\geq 300(96.7 \%), \geq 200(97.7 \%), \geq 100(98.1 \%)$, respectively. The plasma NGAL compared with the enzyme-linked immunosorbent assay (ELISA) has been shown to be an early predictive biomarker of AKI. The NGAL kit, recently developed for point-of-care of plasma specimens, is thought to be a useful and reliable biomarker for the early diagnosis of decreased kidney functions.
\end{abstract}

Keywords: Neutrophil gelatinase-associated lipocalin (NGAL), Acute kidney injury (AKI), Biomarker, Point of care testing

\footnotetext{
This is an Open Access article distributed under the terms of the Creative Commons Attribution Non-Commercial License (http://creativecommons.org/licenses/by-nc/4.0) which permits unrestricted non-commercial use, distribution, and reproduction in any medium, provided the original work is properly cited.

Copyright (C) 2016 The Korean Society for Clinical Laboratory Science. All rights reserved.
}

Corresponding author: Sangwook Park Department of Biomedical Laboratory Science, College of Health, Kyungwoon University, 730, Gangdong-ro, Sandong-myeon, Gumi 39160, Korea

Tel: 82-54-479-2582

Fax:82-54-479-1280

E-mail: spark367@ikw.ac.kr

Received: February 6, 2016 Revised $1^{\text {st. }}$ : February 13, 2016 Revised $2^{\text {nd }}$ : March 1, 2016 Revised $3^{\text {rd. }}$ : March 15, 2016 Revised 4 ${ }^{\text {th }}$ : March 18, 2016 Accepted: March 21, 2016

\section{서 론}

급성 콩팥 손상(Acute Kidney Injury)은 콩팥 기능이 급격한 저 하로 더 이상 체액, 전해질의 평형을 유지할 수 없고 단백 대사산물
의 배설의 지장을 초래하는 질환으로써, 입원환자의 $5 \%$, 중환자실 환자의 30 50\%에서 흔히 발생하며, 그 사망률이 높게 보고되고 있다[1]. 현재 임상에서는 혈청 Creatinine 수치와 소변배출량 (Urine output)이 콩팥 기능 장애의 진단적 표지자로써 가장 많이 
활용하고 있지만, 낮은 민감도로 인해 조기 진단표지자로 활용하기 에는 한계점을 가지고 있다[2].

콩팥 관련 질환은 여러 만성질환처럼 조기발견의 중요성이 강조 되며 [3,4], 신장질환의 선별검사에서 성인의 혈청 Creatinine 참고 치는 $1 \mathrm{mg} / \mathrm{dL}$ 내외이며 혈청 Creatinine 수치의 상승으로 진단하 는 것이 전통적인 방법으로 알려져 있지만, 남녀 성별차이와 급성 콩팥 손상의 초기에는 그 정도를 제대로 반영하지 못한다는 한계가 있으며, 연령에 따라서 참고치 분포가 차이가 남에도 불구하고 이 에 대한 자료는 부족하다[5].

최근 급성 콩팥 손상의 조기 진단표지자(Biomarker)로써 NGAL (Neutrophil Gelatinase-Associated Lipocalin), KIM-1 (Kidney Injury Molecules-1), Interleukin-18, Cystatin C, 그리고 NAG (N-acetyl-beta-D-glucoseamidase) 등 다양한 생물학적 표지자 들이 소개되고 있으나 그 임상적 의미가 아직 명확하게 밝혀지지는 않았다[6]. 급성 심 질환에서는 트로포닌(Troponin)과 같은 생물 학적 표지자가 등장하면서 진단과 치료에 많은 개선이 있었지만, 콩팥 질환에서는 많은 치료약제 개발이 꾸준하게 진전되어 왔음에 도 불구하고 실제 사망률이나 이환율은 별로 개선되지 않았다. 이 러한 이유 중에는 급성콩팥부전을 조기에 찾아낼 수 있는 생물학적 표지자가 없어서 적절한 치료 시점을 놓치기 때문이었다. 다행히 도, 최근에는 기능적 유전체학과 단백질체학과 같은 첨단기술이 개 발되면서 생물학적 표지자로 여러 가지 유전자산물이 밝혀지고 있 다[7]. 급성 콩팥 손상의 원인들은 다양하며 콩팥의 혈류량 감소, 콩 팥 독성물질, 부신 비대증 등을 포함한다. 이들 진단은 소변량감소 와 같은 임상소견, BUN (Blood Urea Nitrogen)/Creatinine 비율 의 증가, 심한 정도에 따라 대사성 산증(Metabolic acidosis), 고칼 륨증(Hyperpotassemia), 체액균형의 변화 및 다른 장기손상 등을 포함한 합병증을 유발하기도 한다[8].

NGAL은 혈청 Creatinine 보다 급성 콩팥 손상을 조기 진단하는 생물학적 표지자로써 중성구나 콩팥 세뇨관의 상피에서 발현되는 단백질인데 여러 가지 원인으로 급성 콩팥 손상이 있게 되면, 급속 하게 증가하는 생물학적 표지자로 알려져 있다. 급성 콩팥 손상 시 Creatinine의 상승 이전에 소변에서 지속적으로 상승하는 결과를 보이므로, 급성 콩팥 손상을 진단할 수 있는 가장 유용한 표지자로 보고되고 있다. 현재는 주로 콩팥기능 이상을 조기에 진단하고 콩 팥 이식 환자의 예후를 판단하는 물질로 활용되고 있으며, 급성 콩 팥 손상의 발병시점이나 지속기간을 추정할 수 있다[9]. 따라서 $\mathrm{NGAL}$ 검사키트의 사용은 1 차적으로 응급처치를 하는 응급 의료 진에게 객관적인 진단적 자료를 제공할 수가 있고 예방처치 및 응 급검사에 도움을 줄 수 있으며[10], 면역형광법(Immunofluoresent assay)을 이용한 NGAL 정량검사는 NGAL의 농도를 신속하
게 정량적으로 측정할 수 있기 때문에 급성 콩팥 질환의 평가와 치 료에 좋은 도구가 될 수 있다[11].

본 연구는 2013년 01월에서 2013년 12월 사이에 대구지역의 응급의료센터를 내원한 콩팥 질환 환자들을 대상으로 NGAL kit 검 사를 ELISA (Enzyme-linked immunosorbent assay) 검사로 측정 한 결과를 비교하여 NGAL kit가 급성 콩팥 질환 환자의 선별적인 검사로써의 가능성을 알아봄으로써, 환자의 조기진단과 치료에 도 움을 주고자 본 연구를 실시하였다.

\section{재료 및 방법}

\section{1. 연구 대상}

2013년 01월부터 2013년 12월까지 대구광역시 소재 C병원 응 급센터를 내원하여 치료를 받은 20 세 이상의 환자로 진단명이 급 성 콩팥 손상이면서 NGAL 검사 측정치가 포함된 84명의 혈액검체 를 대상으로 하였다. NGAL kit의 유용성 평가연구를 위해 응급의 료센터를 내원한 환자 중 42명에게 NGAL검사를 실시한 후 ELISA 로 측정한 결과와 비교분석 하였다. 연구를 진행하기 전에 개인정 보 수집과 이용에 관한 제공 동의서에 자필 서명한 환자에 대해서 연구를 실시하였고, 연구과정 전반에 걸쳐 연구대상자에 대한 윤리 적 측면을 고려하고, 개인 식별 자료는 직접 명시하지 않았으며, 유 추하여 신상을 파악할 수 있는 어떠한 자료도 제시하지 않았다. 본 연구자는 Collaborative Institutional Training Initiative (CITI) Program Biomedical Research 과정을 수료(K-2016-18485898) 하였으며, 질병관리본부 교육시스템에서 생명윤리법 관련 온라인 교육과정을 수료(15-A-00004844)하였다.

\section{2. 검사방법}

NGAL의 정량검사는 NGAL kit (Alere Inc., San Diego, CA, $\mathrm{USA}$ 를 사용하였으며, EDTA 항 응고 전혈을 이용하여 Triage Meter 면역형광분석기(Biosite Inc., San Diego, CA, USA)을 통해 $\mathrm{NGAL}$ 의 농도를 측정 하였다. 검사장치(device)는 형광 나노입자 가 결합한 NGAL 특이 단일클론항체를 포함하는 단일의 플라스틱 카트리지를 사용한다. 검출한계는 $60 \sim 1300 \mathrm{ng} / \mathrm{mL}$ 으로, 검사에 소요되는 시간은 약 15 분으로 Triage Meter 스크린에 측정값이 나 타난다.

ELISA를 이용한 NGAL의 측정은 $3,500 \mathrm{rpm}$ 으로 10 분간 원심 분리하여 얻은 혈청으로 Versa Max ELISA reader (R\&D systems Inc., Minneapolis, MN, USA)로 측정 하였다. 검사방법은 혈청검 체를 60 분 동안 상온에서 방치한 후, $1 \mathrm{X}$ working buffer로 희석하 고 enzyme conjugate를 첨가하여 검체를 30 분 동안 상온에서 방 
치한다. 다시 working buffer로 희석하고 TMB (Tetramethylbenzidine) 기질액을 첨가하여 working substrate solution을 만 든다. 20 분 동안 방치한 후, 정지액(Stop solution)을 넣어 반응을 정지시킨 다음, $450 \mathrm{~nm}$ 에서 흡광도를 측정하였다. NGAL kit 검사 결과와 ELISA 검사결과를 비교하여 민감도, 특이도, 양성예측도, 그리고 음성예측도를 구하였다.

\section{3. 통계분석}

자료의 분석은 윈도우용 SPSS version 18.0 (SPSS Institute, Chicago, IL, USA)를 이용하여 분석하였다. 변수는 $t$-test를 시행 하였고, 결과값은 평균과 표준편차로 표시하였다. 범주형 자료의 비교에는 $\mathrm{x}^{2}$ 을 사용하였고, 기대 값이 작은 경우에는 Fisher의 직 접 확률계산법을 이용하였다. 모든 통계 분석을 위한 유의수준 $(p)$ 은 $p<0.05$ 로 설정하였다.

\section{결 과}

\section{1. 연구 대상자의 특성 및 생화학적 혈액검사}

총 84 명의 연구대상자 중 남자가 50 명(59.5\%)이었고, 여자가 34 명(40.5\%)이었고, 연령대는 60세 미만이 21명(25.0\%)이었으 며, 60세 이상이 63명(75.0\%)이었다(Table 1).

일반적으로 시행되는 응급 7종 생화학적 혈액검사에서 AST (Aspartate aminotransferase) 112.3 \pm 35.6 U/L, ALT (Alanine

Table 1. General characteristics in patient

\begin{tabular}{lllc}
\hline & Variable & N & $\%$ \\
\hline \multirow{3}{*}{ Gender } & Male & 50 & 59.5 \\
& Female & 34 & 40.5 \\
\multirow{4}{*}{ Age } & Total & 84 & 100 \\
& $<60$ & 21 & 25.0 \\
& $\geq 60$ & 63 & 75.0 \\
\hline
\end{tabular}

Table 2. Clinical blood test indicators

\begin{tabular}{lrr}
\hline \multicolumn{1}{c}{ Variable } & Mean & \multicolumn{1}{c}{ SD } \\
\hline AST $(\mathrm{U} / \mathrm{L})$ & 112.3 & 35.6 \\
ALT $(\mathrm{U} / \mathrm{L})$ & 95.7 & 29.5 \\
BUN $(\mathrm{mg} / \mathrm{dL})$ & 84.6 & 35.6 \\
Creatinine $(\mathrm{mg} / \mathrm{dL})$ & 5.3 & 2.4 \\
Na $(\mathrm{mEq} / \mathrm{L})$ & 138.2 & 3.2 \\
K $(\mathrm{mEq} / \mathrm{L})$ & 4.2 & 1.2 \\
$\mathrm{Cl}(\mathrm{mEq} / \mathrm{L})$ & 98.5 & 3.9 \\
NGAL $(\mathrm{ng} / \mathrm{mL})$ & 625.3 & 125.8 \\
\hline
\end{tabular}

Abbreviation: SD, standard deviation; AST, aspartate aminotransferase; ALT, alanine aminotransaminase; BUN, blood urea nitrogen; NGAL, neutrophil gelatinase-associated lipocalin. aminotransferase) $95.7 \pm 29.5 \mathrm{U} / \mathrm{L}, \mathrm{BUN}$ (Blood Urea Nitrogen) $84.6 \pm 35.6 \mathrm{mg} / \mathrm{dL}$, Creatinine $5.3 \pm 2.4 \mathrm{mg} / \mathrm{dL}$, Sodium $138.2 \pm 3.2 \mathrm{mEq} / \mathrm{L}$, Potassium $4.2 \pm 1.2 \mathrm{mEq} / \mathrm{L}$, Chlorine $98.5 \pm 3.9 \mathrm{mEq} / \mathrm{L}, \mathrm{NGAL} 625.3 \pm 125.8 \mathrm{ng} / \mathrm{mL}$ 이었다(Table 2).

\section{2. 혈액검사와 NGAL과의 상관관계}

응급 7종 생화학적 혈액검사와 NGAL과의 상관관계에서 NGAL 이 증가할수록, Creatinine이 유의하게 증가하였다( $p$-value $=0.018)$. AST와 ALT의 상관계수는 각각 $-0.168,-0.171$ 로 통계적으로 유 의하지 않았고, BUN, Sodium, Potassium, Chlorine 또한 통계적 으로 유의하지 않았다(Table 3).

\section{NGAL kit와 ELISA 민감도 특이도}

응급의료센터를 내원한 환자의 NAGL kit와 ELISA의 민감도는 $\geq 300$ (92.2\%), $\geq 200$ (95.6\%), $\geq 100$ (99.6\%), 특이도는 $\geq 300$ (95.1\%), $\geq 200$ (97.3\%), $\geq 100$ (99.4\%)으로 조사되었으며, 이에 따른 양성예측도는 $\geq 300$ (93.3\%), $\geq 200$ (93.4\%), $\geq 100$ (99.2\%), 음성예측도는 $\geq 300$ (96.7\%), $\geq 200$ (97.7\%), $\geq 100$ (98.1\%) 이였다(Table 4).

\section{고 찰}

급성 콩팥 손상(Acute kidney injury, AKI)은 입원 환자의 입원 기간은 물론 사망률을 증가시키고 장기적으로는 만성 신장병의 발

Table 3. Correlation coefficients between blood tests and NGAL

\begin{tabular}{lrc}
\hline \multicolumn{1}{c}{ Variable } & NGAL & $p$-value \\
\hline AST $(\mathrm{U} / \mathrm{L})$ & -0.168 & 0.325 \\
$\mathrm{ALT}(\mathrm{U} / \mathrm{L})$ & -0.171 & 0.315 \\
$\mathrm{BUN}(\mathrm{mg} / \mathrm{dL})$ & 0.215 & 0.065 \\
Creatinine $(\mathrm{mg} / \mathrm{dL})$ & 0.385 & 0.018 \\
$\mathrm{Na}(\mathrm{mEq} / \mathrm{L})$ & 0.154 & 0.425 \\
$\mathrm{~K}(\mathrm{mEq} / \mathrm{L})$ & 0.133 & 0.412 \\
$\mathrm{Cl}(\mathrm{mEq} / \mathrm{L})$ & 0.124 & 0.398 \\
\hline
\end{tabular}

Table 4. Characteristics of NGAL and ELISA at various cut-off values

\begin{tabular}{lccc}
\hline \multirow{2}{*}{ Variable } & \multicolumn{3}{c}{ Cut-off } \\
\cline { 2 - 4 } & $\geq 300$ & $\geq 200$ & $\geq 100$ \\
\hline Sensitivity (\%) & 92.2 & 95.6 & 99.6 \\
Specificity (\%) & 95.1 & 97.3 & 99.4 \\
Positive predictive value (\%) & 93.3 & 93.4 & 99.2 \\
Negative predictive value (\%) & 96.7 & 97.7 & 98.1 \\
\hline
\end{tabular}

Abbreviation: ELISA, enzyme-linked immunosorbent assay. 
생과도 연관이 있으며, 많은 연구에서 혈청 Creatinine은 사구체 여과율이 현저히 감소된 이후에 변화를 보여, 정확한 예후를 판정 하고 조기에 예방적 치료를 시행하는 근거로는 부적합하다는 의견 이 지배적이다[12].

임상적으로 급성 콩팥기능 부전을 판단 할 수 있는 혈청 Creatinine의 상승이나 소변량의 감소 등은 콩팥 손상이 진행된 이 후에 나타나며[13], 신장 이식 후 소변량의 변동이 천천히 감소하는 경우, 급성 거부반응과 감별 진단이 임상적으로 진단하기는 매우 어려워 초기 콩팥 손상을 알려주는 예민한 표지자의 필요성이 제기 되어 왔다[14]. 사구체여과율(Glomerular filtration rate, GFR)은 콩팥이 일정시간 동안 특정물질을 완전히 제거할 수 있는 혈장량으 로 정의되며, 콩팥기능 평가의 중요한 표지자로 이용되었다[15]. 사구체여과율 측정의 표준방법은 Inulin, Iohexol, ${ }^{51} \mathrm{Cr}-\mathrm{EDTA}$, 99mTC-labeled diethylenetriamine pentaacetic acid (DTPA), ${ }^{125}$ I-labeled iothalamate 등 외부 표지자의 제거율을 측정하는 것 이다. 하지만, 환자에게 표지약제를 직접 주입해야 하고 시간이 많 이 걸려 상용 검사로는 시행하기 어렵기 때문에 Creatinine, BUN, 2-microglobulin 등을 이용하여 사구체여과율을 추정하는 방법 이 사용되고 있으며, 그 중 혈청 Creatinine이 임상적으로 가장 많 이 사용되고 있다[16].

NGAL은 활성화된 호중구에서 초기에 발견된 lipocalin superfamily에 속하는 $25 \mathrm{kDa}$ 의 분자량이 작은 단백질이며, 콩팥 의 허혈성 손상, 감염, 악성종양, 신 세뇨관 손상 등이 일어났을 때, 콩팥의 헨넬고리(Henle's loop)나 원위 세뇨관에서 발현된다. 사 구체에서 여과된 후, 근위세뇨관 에서도 재흡수되어 발현될 수 있 으며 혈장 및 소변에서도 발견 할 수 있다[17]. NGAL 정량검사는 소변 및 혈액(혈장 또는 혈청)에서 급성 콩팥 손상 시 생성되는 $\mathrm{NGAL}$ 을 측정함으로써, 급성 콩팥 손상의 조기진단 및 손상의 정도 를 평가하는 검사이다. 이러한 NGAL의 발현은 콩팥 독성 손상 또 는 허혈에 의한 콩팥 손상에서 의미있게 증가하며, 급성 콩팥 손상 의 생체표지자로 콩팥기능 이상의 조기 진단과 콩팥 이식 환자의 예후를 판단하는 중요한 물질로 알려져 있다[18].

최근 새로운 급성 콩팥 손상의 표지자를 발견하려는 노력이 있 었음에도 불구하고 여전히 혈청 Creatinine이 유일한 지표로 사용 되고 있는 것이 현실이며 급성 콩팥 손상의 표지자는 조기발견과 진단, 그리고 정확한 예후를 판정하는 지표로 사용되어야 하지만, 급성 콩팥 손상의 발생이 단순히 신장만의 문제로 국한 되는 것이 아니라 다양한 원인 질환 및 다른 전신장기와 연관하여 나타나므로 이러한 임상적 요구를 충족하는 새로운 표지자를 찾기란 어려운 일 이다.

Yilmaz A 등[19] 의 연구에서는 콩팥 질환 환자에서 NGAL 농도
가 상승하는 것을 확인하였고 급성 콩팥 질환의 초기 진단 및 중증 도 추정에 NGAL을 이용할 수 있다고 하였다. 또한 응급실을 기반 으로 한 연구에서는 NGAL의 측정값은 콩팥 관련 질환의 좋은 지표 이며 콩팥 관련 질환에서 NGAL을 이용할 수 있다고 하였다[20].

본 연구에서는 대구지역 응급의료센터에 내원한 급성 콩팥 손상 환자의 일반적인 특성을 조사하고 검사실 결과와의 상관관계를 분 석하였다. 응급 7종 생화학적 혈액검사와 NGAL과의 상관관계에 서 NGAL이 증가할수록 Creatinine이 유의하게 증가하였다. 하지 만 AST, ALT, BUN, Sodium, Potassium 그리고, Chlorine의 상관 관계는 통계적으로 유의하지 않았다.

NAGL kit와 ELISA의 민감도는 $\geq 300$ (92.2\%), $\geq 200$ (95.6\%), $\geq 100$ (99.6\%), 특이도는 $\geq 300$ (95.1\%), $\geq 200$ (97.3\%), $\geq 100$ (99.4\%)로 조사되었으며, 양성예측도는 $\geq 300$ (93.3\%), $\geq 200$ (93.4\%), $\geq 100$ (99.2\%), 음성예측도는 $\geq 300$ (96.7\%), $\geq 200$ (97.7\%), $\geq 100$ (98.1\%)로 조사되어, 선행연구[19,20]에서 밝혀진 바와 같이 NGAL 정량검사는 혈액 검체에서 급성 콩팥 손상의 정도 를 평가하는 방법으로 조기 진단 및 예후를 예측함에 있어서 신속 하고 유용하게 이용할 수 있을 것으로 생각한다. 본 연구의 한계점 으로는 NGAL 수치는 체액 상태, 약물 등의 영향을 받을 수 있으며, 이에 대한 기준이나 평가가 현재까지는 명확하지 않다는 점이다 [21]. 또한 $\mathrm{NGAL}$ 측정 상한치가 $1300 \mathrm{ng} / \mathrm{mL}$ 이기 때문에 1300 $\mathrm{ng} / \mathrm{mL}$ 이상인 환자의 평가가 제한적이고, 조사지역이 단일지역이 라는 점은 보완할 필요가 있다. 따라서 통계적 유의성을 나타내려 면 충분한 피험자의 수치와 추가적인 검사요인뿐만 아니라 전국 지 역을 대상으로 하는 연구가 필요할 것으로 생각되고, 앞으로 이러 한 제한점들을 보완하는 전향적인 다 기관 연구가 필요할 것으로 사료된다.

이러한 한계점에도 불구하고, 응급의료센터의 콩팥 질환 환자들 에게 NGAL kit검사는 간단하고 신속하게 결과를 확인할 수 있는 현장검사(Point of care testing, $\mathrm{POCT}$ 로서, 급성 콩팥 손상과 관 련된 콩팥 기능에 대한 평가와 치료에 도움이 될 수 있을 것으로 사 료되고, 이러한 현장검사의 단점으로는 훈련을 받지 않은 비 전문 가에 의해 검사가 행해지거나, 정도관리(Quality control)가 이루 어지지 않은 상황에서 검사가 시행되고 결과 보고가 체계적으로 이 루어 지지 않을 수도 있다는 점이다. 따라서 현장검사는 그 유용성 이 확실하게 입증된 검사에 한해서 실시되고, 정도관리 시스템이 구축되어 지속적인 관리가 이루어질 수 있는 경우에 한해 도입되고 운영되어야 할 것이다.

마지막으로 NGAL kit의 사용은 급성 콩팥 손상환자에게 1차적 으로 접하고 응급처치를 하는 응급의료진에게 정확하고 객관적인 진단적 자료를 제공함으로써 예방처치 및 응급검사에 많은 도움을 
줄 수 있을 것으로 생각한다.

\section{요 약}

급성 심 질환 환자는 트로포닌(troponin)과 같은 생물학적 표지 자(biomarker)가 등장하면서 진단과 치료에 많은 개선이 있었다. 콩팥 질환에서는 많은 치료약제 개발이 꾸준하게 진전해 왔음에도 불구하고 실제 사망률이나 이환률은 별로 개선되지 않았다. 급성 콩팥 손상 환자를 대상으로 응급의료센터에서 측정한 NGAL의 측 정치는 NGAL이 증가할수록 Creatinine이 유의하게 증가 하였다. 그러나, $\mathrm{AST}, \mathrm{ALT}, \mathrm{BUN}, \mathrm{Na}, \mathrm{K}, \mathrm{Cl}$ 과의 상관관계는 통계적으로 유 의하지 않았다. NAGL kit와 ELISA의 민감도는 $\geq 300(92.2 \%), \geq$ 200 (95.6\%), $\geq 100$ (99.6\%), 특이도는 $\geq 300$ (95.1\%), $\geq 200$ (97.3\%), $\geq 100$ (99.4\%)로 조사되었으며 양성예측도는 $\geq 300$ (93.3\%), $\geq 200$ (93.4\%), $\geq 100$ (99.2\%), 음성예측도는 $\geq 300$ (96.7\%), $\geq 200$ (97.7\%), $\geq 100$ (98.1\%)로 조사되었으며, 급성 콩 팥 손상의 정도를 평가하는 검사로써 조기 진단 및 예후를 예측함 에 있어서 환자의 치료의 결정에 유용하게 이용 될 수 있다. 향 후응 급의료센터에서 콩팥 질환 환자의 중증도를 평가하고 치료 방향을 결정하며, 예후를 예측하는데 있어서 NGAL kit 검사가 도움이 될 수 있다고 생각한다.

\section{Acknowledgements: None}

Funding: None

Conflict of interest: None

\section{References}

1. Lisowska MB. Serum and urinary biomarkers of acute kidney injury. Blood Purification. 2010;29:357-365.

2. Haase FA, Bellomo R, Devarajan P, Story D, Matalanis G, Dragun $D$, et al. Novel and conventional serum biomarkers predicting acute kidney injury in adult cardiac surgery a prospective cohort study. Critical Care Medicine. 2009;37:553-560.

3. Striker GE. Report on a workshop to develop management recommendations for the prevention of progression in chronic renal disease. Nephrol Dial Transplant. 1995;10:290-292.

4. Hostetter TH. Prevention of the development nd progression of renal disease. J Am Soc Nephrol. 2003;14(Suppl):S144-147.

5. Kwon SY, Na YA. Concentration of serum and urine creatinine in children and adolescents. Korean J Clin Lab Sci. 2014; 46:117-123.

6. Han JS. Urinary diagnostic indices in acute kidney injury. The Korean Journal of Nephrology. 2009;28:169-172.

7. Haase M, Bellomo R, Devarajan P, Schlattmann P, Haase F. Accuracy of NGAL in diagnosis and prognosis in AKI: a system- atic review and meta-analysis. Am J Kidney Dis. 2009;54: 1012-1024.

8. Yang HN, Boo CS, Kim MG, Jo SK, Cho WY, Kim HK. Urine nutrophil glatinase-asociated lipocalin an independent predictor of adverse outcomes in acute kidney injury. American Journal of Nephrology. 2010;31:501-509.

9. Vaidya VS, Ferguson MA, Bonventre JV. Biomarkers of acute kidney injury. Annual Review of Pharmacology and Toxicology. 2008;48:463-493.

10. Lee SJ, Lim SO, Jeong JY, Park MJ, Park JE. The clinical pathology characteristics and tetanus quick stick evaluation for tetanus patients in daegu emergency medical center. Korean J Clin Lab Sci. 2014;46:12-16

11. Dent CL, Ma Q, Dastrala S, Bennett M, Mitsnefes MM, Barasch J, et al. Plasma neutrophil gelatinase-associated lipocalin predicts acute kidney injury morbidity and mortality after pediatric cardiac surgery: a prospective uncontrolled cohort study. Critical Care. 2007;11:R127. DOI: 10.1186/cc6192

12. Al Ismaili Z, Palijan A, Zappitelli M. Biomarkers of acute kidney injury in children: discovery, evaluation, and clinical application. Pediatr Nephrol. 2011;26:29-40.

13. Choi MJ, Park SH, Kim CD, Kim YL, Kwon TH, Kim IS, et al. Identification of TGF- $\beta$-induced gene product, $\beta$ ig-h 3 in ischemic acute renal failure. The Korean Journal of Nephrology. 2007;26:301-310.

14. Lee SR, Kwon OJ, Koh BH, Kwak JY. Serial changes of serum creatinine and resistive index to predict acute rejection after renal transplantation. J Korean Soc Transplant. 1999; 13: 123-132.

15. Ha JS, Ryoo NH, Kim JR, Jun DS, Kim HC, Kim YJ. Cystatin C as a marker for early renal impairment. Korean J Lab Med. 2004;24:27-32.

16. Laterza OF, Price CP, Scott MG. Cystatin C an improved estimator of glomerular filtration rate. Clinical Chemistry. 2002; 48:699-707.

17. Mishra J, Ma Q, Prada A. Identification of neutrophil gelatinase-associated lipocalin as a novel early urinary biomarker for ischemic renal injury. J Am Soc Nephrol. 2003;14:2534-2543.

18. Grande AD, Giuffrida C, Carpinteri G, Narbone G, Pirrone G, Mauro $\mathrm{AD}$, et al. A novel biomarker for the early diagnosis of acute kidney injury in the emergency department. European Review for Medical and Pharmacological Sciences. 2009; 13:197-200.

19. Yilmaz A, Sevketoglu E, Gedikbasi A, Karyagar S, Kiyak A, Mulazimoglu M, et al. Early prediction of urinary tract infection with urinary neutrophil gelatinase-associated lipocalin. Pediatr Nephrol. 2009;24:2387-2392.

20. Nickolas TL, O'Rourke MJ, Yang J, Sise ME, Canetta PA, Barasch $\mathrm{N}$, et al. Sensitivity and specificity of a single emergency department measurement of urinary neutrophil gelainase-associated lipocalin for diagnosing acute kidney injury. Ann Intern Med. 2008;148:810-819.

21. Lee JY, Kim JY, Park SO, Lee KR, Baek KJ, Hong DY. Plasma neutrophil gelatinase-associated lipocalin is an early marker of acute kidney injury. J Korean Soc Emerg Med. 2013;24: 157-163. 